\title{
Intellectual and cultural work in times of austerity Introduction
}

\author{
Emma Park, Derek R. Peterson, Anne Pitcher and \\ Keith Breckenridge
}

How have African cultural and intellectual institutions worked under conditions of austerity? Through what acts of remediation and choreographies of survival have university faculty, staff and students, playwrights, artists, publishers, journalists and curators made up the gap between ambition and deficit, between the state of the art and material scarcity? In this part issue we expose the often unacknowledged labour and expertise of African intellectuals, administrators and artists whose commitments and sense of vocation have made institutions work in spite of crippling social and economic challenges. We study how universities, archives, research centres, museums and publishing houses have been reorganized and redistributed in response to hardship, shortage, cuts and constraints, as people work to market cultures and make history in times of deprivation.

In its contemporary definition, austerity does not reflect a cohesive economic doctrine: it refers to general ideas about the consequences of the withdrawal of the 'state in the economy' (Blyth 2013: 17). In fact, the term has a much longer and more complex genealogy than conventional understandings acknowledge. In Eastern and Southern Africa, over many generations, the majority have confronted bleak economic and institutional predicaments that realized a surplus for the few. Whereas roads, railways and harbours attracted extractive colonial investments (Rodney 1972; Vail and White 1980), the infrastructures of culture - schools, libraries, universities, archives - have been bitterly under-resourced for a century, particularly beyond the central precincts of capital cities. In this introductory article we unpack this longer history of austerity.

\footnotetext{
Emma Park is an Assistant Professor of History at The New School for Social Research. Her work focuses on the cultural politics of infrastructures, state-corporate entanglements, and the politics of technical expertise in Kenya. She is currently completing a book manuscript on these topics provisionally titled Infrastructural Attachments: austerity, sovereignty, and the politics of expertise in Kenya. Email: parke@newschool.edu

Derek R. Peterson is Professor of History and African Studies at the University of Michigan and co-author of The Unseen Archive of Idi Amin: photographs from the Uganda Broadcasting Corporation (Prestel, 2021). Email: drpeters@umich.edu

Anne Pitcher is a Professor of Political Science and Afroamerican and African Studies at the University of Michigan. Her recent publications have examined state capture, party politics and urban political economy, largely in Angola, Mozambique, Kenya and South Africa. She is currently studying election-related violence across Africa. Email: pitchera@umich.edu

Keith Breckenridge is a Professor and Deputy Director at Wiser. He writes about the cultural and economic history of South Africa, particularly the gold-mining industry, the state, and the development of information systems. He is currently writing about infrastructures of biometric civil registration and credit surveillance developing on the African continent. Email: keith@breckenridge.org.za

(C) The Author(s), 2021. Published by Cambridge University Press. This is an Open Access article, distributed under the terms of the Creative Commons Attribution licence (http://creativecommons. org/licenses/by/4.0/), which permits unrestricted re-use, distribution, and reproduction in any medium, provided the original work is properly cited.
} 
The concept's contemporary imprecision is belied by its historical depth. Austerity is an old English word, making its way into English before the fourteenth century. John Wycliffe - the theologian and translator who formalized the English language - used the term in his 1380 tract against the power and privileges of the papacy (Matthew 1880). Wycliffe wanted the clergy to live lives of simplicity, freed from the oversight of secular authorities and beholden only to the gospel. In the Oxford English Dictionary, 'austerity' is given a further definition: it refers to the physical world, to the weather and, especially, to landscapes. And then there is the more common, modern usage that the OED dates unusually precisely from 1942. We owe this interpretation of austerity to John Maynard Keynes: it was the object of his attack on the laissez-faire argument that debt should not be used to sustain social welfare during economic downturns. This is the definition that has become dominant in the social sciences (Blyth 2013; Bear 2015).

Here we suggest that austerity - in its descriptive and its prescriptive meanings is a useful analytic for understanding the history of the African continent since the earliest days of colonial occupation. Colonial governments modelled their authority on severe, exalted paternalism where the fulfilment of work requirements was considered a moral and cultural obligation. Political movements and economic policies (in theory and sometimes in practice) made a virtue of self-denial and the rejection of luxury. More recently, the fraught relationship between debt and welfare has dominated most African countries. As a description of a situation and as a set of policies, austerity does not fit all the regions of the continent equally well - perhaps especially not the relatively densely settled, and prosperous, coastal regions of West Africa, nor the major oil-exporting countries, where, as Célestin Monga would insist, asceticism is strange (Monga 2016: 86) - but it is useful in understanding the political economies of Central, Eastern and Southern Africa.

The enforced reconfiguration of economy and society in the 1980s and 1990s is the face of austerity with which most observers are familiar. Thirty-six African countries were subjected to nearly 250 'adjustment agreements' with international financial institutions (Harrison 2007: 191). Cost cutting by governments to address deficits and to balance budgets meant that vital public services such as the provision of clean water, sanitation, education and healthcare either disappeared or were drastically reduced. Public employment and public pensions were trimmed or eliminated. Social grants for those who were the most marginalized evaporated. Scholars have explored how failing public infrastructures, where they existed, were haphazardly replaced by commercially resourced projects and a pervasive and quixotic NGOism (Rottenburg 2009; Mann 2014; Piot 2010).

Complementing the vast literature on the consequences of neoliberalism, we deliberately focus on the practices of remediation that occur in times of austerity. Provisions for the institutions that curate and superintend intellectual life are often the first to disappear, or be radically reconfigured, when conditions of austerity prevail. In their conceptualization of ordinary bureaucracy, scholars working on the practical norms of African states refer repeatedly to the gap between norms 'on paper' and those that exist 'on the ground' - highlighting a distinction between bureaucracy in theory and practice (Bierschenk 2014; Olivier de Sardan 2015 on grounded theory; Martin 2015). We suggest something conceptually different. Under conditions of severe constraint and shortage, the remediation of paperwork is made into the very grounds of administration. Paperwork - its 
management, its loss, its organization - channels and forecloses knowledge about the political world, making possible some forms of action (but not others), some forms of accountability (but not others), and some forms of organization (but not others). Archives make some categories of people legible to authorities of the state, which is why so many people have created their own collections of records in tin trunks, cupboards and other repositories (Barber 2006). For African officials in the provinces, paperwork involves a continuous set of palliative compromises with the very limited resources that are available locally (see Lentz 2014; Eckert 2014). In many places the basic tools of documentary bureaucracy - paper, delivery services, filing cabinets, computers, printers and the skills to use them - are always scarce and hard to find (Bierschenk 2014; Hamani 2014; Peterson, this issue).

This issue explores austerity's material effects with regard to the production, preservation and circulation of knowledge. The articles emerge out of a June 2018 conference convened at the Universidade Eduardo Mondlane in Maputo, Mozambique. The conference was part of a longer-running collaboration, funded by the Andrew W. Mellon Foundation, that joins the Wits Institute for Social and Economic Research with the African Studies Center at the University of Michigan. The Maputo conference brought together scholars working at sites across the continent for a sustained conversation about the temporalities and material effects of austerity, focusing specifically on how cultural architects and stewards of state and non-state institutions have negotiated conditions of austerity.

All of the articles collected here are about institutions - archives, universities, publishing houses - that curate culture and generate knowledge. These institutions bear a huge moral and intellectual burden in postcolonial Africa. They have been tasked with the work of preserving endangered cultural forms, safeguarding morality, conserving the momentum of past struggles, hymning the victories of old, and commemorating honourable martyrs. The authors published here bring to light the people who labour to make these institutions work. They inquire into their ambitions, their motives and their dedication, and they highlight the restrictions they have confronted. Their rhetorical and political importance notwithstanding, curatorial institutions of all kinds have had to operate in conditions of dramatic shortage. Curators, artists, publishers, lecturers and archivists have had to make up the difference between the political and moral weight placed on the institutions they superintend and the facts of shortfalls, scarcity and lack.

In this introductory essay we chart how conditions of austerity have shaped knowledge production over time. There are three points of focus. First, we call attention to the temporality of austerity and to the 'time depth of cross-historical processes' (Cooper 2001: 190) manifest in its occurrence. We decouple austerity from its association with contemporary capitalism and call attention to colonial expressions of austerity and people's strategies of remediation. Although we recognize the risk of collapsing diverse expressions of marginalization and poverty into the concept of austerity, we argue that the historical meanings of austerity outlined above also speak to the experiences of people living on the continent under colonialism.

The same arrangements that structure austerity generally also apply to the production of cultural forms. That is our second point. Austerity produces novel configurations of authority and encourages practices of making-do. In places where institutions operate under conditions of material dearth, curators and artists must improvise. Yet, in Africa and elsewhere, cultural forms rarely provide evidence of the working conditions under which they were produced. 
This part issue draws back the curtain obscuring the backstage of cultural life. We bring to light the institutions in which humanistic, literary and artistic work is created.

Finally, we call attention to the human actors whose knowledge and dedication make cultural institutions function. People develop capabilities, skills and aptitudes as a result of their long engagement with technologies and infrastructures. They become 'technological prosthetics', extending the work of inanimate machines, conducting repairs, doing maintenance (Park 2017). Recycling, repurposing, recomposition and redefinition are the curatorial modes in which people must work. Their dedication to their craft grows out of a proprietary feeling of ownership over the infrastructural interface, and a sense of stewardship. These impulses can motivate works of extraordinary self-sacrifice or selfish opportunism.

\section{Austerity before austerity}

As Sara Berry once argued, colonial governments in Africa sought to achieve 'hegemony on a shoestring' (Berry 1992). Roads, railroads, government buildings and other infrastructures were built and maintained by Africans. According to one recent study, forced labour was the most important single component of early colonial budgets in French West Africa (van Waijenburg 2018). Africans' energy, time and expertise upheld the architecture of colonial government. In a similar manner, political traditions were turned into instruments of colonial government. The 'decentralized despotism' of indirect rule transferred to African chiefs and rulers the expense of maintaining order, adjudicating civil disputes, and upholding colonial directives (Mamdani 1996).

The routine paperwork of governance in Africa was severely constrained following metropolitan cuts in the 1920s. The Geddes Axe commission, while mainly tasked with reducing the costs of public education in the United Kingdom following World War One, made itself felt on the African continent. In South Africa, Kenya and Nigeria, the Geddes Axe fell heavily on the specific forms of documentation that had been aimed at Africans, especially in the registration of people and property. In Kenya, the 'Geddes Committee' (briefly) contemplated the dismantling of the 'kipande' labour and tax registration system (Ross 1968: 192). In South Africa, Smuts used the budget crisis to kill working systems of birth and death registration for rural Africans that undergirded all social and welfare spending (Breckenridge 2014: Chapter 3). The same crisis was used to dismantle the most progressive and capacious elements of nineteenth-century Native Administration (Dubow 1989: 81-95) and to strip the modernizing agenda out of Shepstone's ambivalent authoritarianism (Guy 2013). The passing of the 1927 Native Administration Act compensated for the retreat of administrative capacity by bolstering despotic forms of rural authority - a model that spread widely across the continent (Mamdani 1996).

Public education similarly received meagre funding in the early twentieth century. Up to World War Two, the colonial government in Mozambique restricted formal primary education - the bulk of which was provided by Catholic missions - to two districts in the south of the colony. By state decree, schools were strictly segregated into 'elementary schools' directed at 'non-indigenous peoples' and 'rudimentary schools' for the 'indigenous' population (Newitt 
1995: 440). The Accordo Missionário of 1940, which governed the purposes of indigenous education provided by missions, advocated the virtuous asceticism prized by Wycliffe. It envisioned:

the perfect training of the indigenas in national and moral ideals ... and the acquisition of habits and aptitudes for work ... Moral ideals being understood to include the abandonment of idleness and the training of future rural workers and artisans to produce sufficient for their needs and their social obligations. (cited in Newitt 1995: 479)

Institutions and programmes that were meant to promote accountability and enable civic participation in political life across the continent were starved of resources. It was a way of shrinking the political field, of depriving Africans of the power to criticize government. In Mozambique, the paperwork that the early colonial regime deemed important was destined for departure. Until the Arquivo Histórico de Moçambique (Mozambique Historical Archive) was created in the mid-1930s, most government documents were sent to Lisbon for others to read (Liesegang 2000: 471). In Uganda, the government did not employ an archivist until the early 1950s. Much of the archivist's work involved the destruction of files that overflowed in government offices. As Taylor shows in this issue, access to archives was strictly policed; even well-connected scholars found it difficult to access government information.

Following World War Two, there was a shift in the political logic of government budgeting. Most colonial powers adopted Keynesian approaches to post-war recovery, stressing government spending as a means of spurring economic growth. As metropolitan governments began to engage in direct financing, they also created institutions such as the Colonial Development Corporation and the Fonds d'Investissement pour le Développement Économique et Social (FIDES) to undertake large-scale investments in British and French colonies respectively (Freund 2010: 39). In the Portuguese colonies, colonial officials likewise launched elaborate development plans that promised to increase agricultural production, support agro-industrial processing, and expand labour-intensive industrialization (Pitcher 1993: 180-2).

Expansionary investment in production was not primarily designed to benefit colonial subjects, but rather to offset the costs of the war for the metropoles and to provide new markets for companies facing weak demand in post-war Europe. Initiatives that were meant to benefit African commoners had to be pursued on the cheap. In British East Africa, for example, colonial officials hoped to launch a programme of mass education using radio and film, but the limited reach of electricity grids beyond colonial capitals rendered such aspirations illusory. In the face of these limitations, colonial officials sent mobile units on tours throughout the countryside, where crew members broadcast radio programmes, circulated broadsheets and screened films designed to 'make the minds of the Africans in the Reserves sympathetically disposed towards the acceptance of improved conditions of life'. ${ }^{1}$ These projects of cultural reform

\footnotetext{
${ }^{1}$ Kenya National Archives (KNA), DC/MUR/3/10/2: Cinema and Stage, Ambrose C. Coghill, 'Mambo Leo: a memorandum on the education of East African natives by means of the mobile cinema projection units'.
} 
were freighted with pedagogy: programming endeavoured to 'promote the administration's technocratic, modernizing projects' in a manner that would appeal to 'African psychology' (Ivaska 2011: 11).

Decolonization raised expectations that independence would usher in a period of material transformations, levelling out the global inequalities of the past (Arrighi 2007: 9). Despite their ideological differences, independent governments saw the state as the vehicle through which they would address the austerity inflicted on Africans by colonialism and bring development to their countries. Policies of nationalization and indigenization were meant to relocate economic power into the hands of either the state or domestic capitalists (Pitcher 2002). Independent African governments had equally ambitious plans in the field of education and culture. As Mubai's article observes, following independence in 1975, the Mozambican government dramatically expanded access to education, paying particular attention to the education of girls and adults. After declaring literacy a national priority, it established a nationwide campaign between 1978 and 1983 to combat illiteracy and made provision for adult education. The government had some success: the illiteracy rate, which was estimated to be around 93 per cent in 1975, shrunk to 58 per cent by 1990 (Ngunga 1999). The government also paid attention to curatorial institutions. As Machava and Gonçalves detail in their contribution, the Arquivo Histórico de Moçambique made strenuous efforts after independence to collect records and documentation of the colonial period, especially material from the provinces.

Economic growth did not, however, necessarily lead to the enrichment of the poor. In Kenya, gross national product (GNP) per capita rose nearly 30 per cent in the decade after independence in 1963. The growth was fuelled by peasant farmers, who were newly permitted to grow coffee and other valuable cash crops (Cooper 2002: 93). But Jomo Kenyatta had little time for the demands of the poor. When Bildad Kaggia - one of the heroes of the Mau Mau movement - argued that the Gikuyu poor should be resettled en masse on farms formerly owned by white settlers, Kenyatta excoriated him before a large audience. 'I can assure you that even in so-called Communist countries such as Russia no one gets anything for nothing,' Kenyatta pronounced. 'There are no free things. ${ }^{2}$ Loyalists who had allied with the colonial government during the Mau Mau war enjoyed great advantages: their children were airlifted to the United States, where they enrolled in American universities and earned American degrees (Harper 2006). The children and grandchildren of Mau Mau activists, by contrast, were a permanent rural underclass, educated in poorly equipped schools (Branch 2009). The rationale for Kenyatta's government was called 'harambee', or self-help. At every public gathering, Kenyatta would stand before the crowd, flywhisk in hand, and shout 'harambee' three times, inviting the audience to respond in kind. In this way, shortfalls in budgetary provision were made to appear as morally edifying tests of will.

In the 1970s, international institutions and African governments confronted a global economic crisis. As Janet Roitman has argued, crisis thinking is a narrative device: it justifies dramatic policies and legitimates authoritarian programmes (Roitman 2013). In Africa, the crisis of the 1970s fuelled transformations in the

\footnotetext{
${ }^{2}$ 'Kenyatta lashes critic’, South Bend Tribune, 11 April 1965, p. 5.
} 
political theory of government and invited reformist regimes to moderate their citizens' appetites, curb their consumerist ambitions, and teach them how to behave. This was particularly true in socialist states. In Mozambique, for example, the FRELIMO government sought to 'cleanse' urban areas of the morally suspect, compromised and unproductive by shipping thousands of men and women to re-education camps located in the remote north. As Benedito Machava has recently shown, the programme of moral and political reorientation was conducted under conditions of severe austerity: imprisoned people had to construct their own houses, grow their own food and fabricate their own clothes with very minimal resources (Machava 2018). Tanzania's government similarly sought to reorient the appetites of urban people. From 1973, tens of thousands of urban dwellers were compulsorily relocated to collectivized villages, where they were made to farm and engage in handwork (Ivaska 2011; Lal 2015). Ujamaa, or 'familyhood', was a means of directing Tanzanians' ambitions and behaviours toward a common morality. In these and in other instances, governments purposefully imposed austerity on their citizens as an aspect of their larger campaign against neo-colonial control over the economy and cultural forms. The call of ascetic living was joined to the demand for discipline and financial independence.

For many countries in the global South, International Monetary Fund (IMF) and World Bank policies of the 1980s hollowed out an already weak public sector, often transforming it into a means of private sector accumulation (Bear 2017). NGOs began to perform tasks previously undertaken by the state; private voluntarism replaced public responsibilities. As Ngunga writes, literacy campaigns in Mozambique failed for many reasons - including the insistence on teaching in Portuguese, which was the first language of only a quarter of Mozambicans (Ngunga 1999). Nevertheless, when the government withdrew its involvement in the 1990s, secondary school students (including one of our contributors, Ben Machava) voluntarily took on the teaching of literacy.

Financial austerity also consolidated the 'gatekeeper state' that colonial powers had inaugurated (Cooper 2002: 160; see also Bayart 2010). Neoliberal austerity offered a sharp contrast to a Keynesian economic model. It was not the state's role to protect the public from 'market' fluctuations. Instead, it was the role of the state to create political and economic conditions amenable to the market's expansion into previously non-commoditized domains of life. As Brenda Chalfin has argued in this regard, austerity is not the retraction of the state per se, but the reordering of public and private both within the state and along its edges (2010: 37). Everywhere, institutions suffered. The most basic tools of governance - paper, computers, printers, vehicles - became increasingly scarce as budget lines shrank. Schools lacked teachers, desks, pens, notebooks, and all the other materials required for learning.

\section{The social lives of institutions}

With a few notable exceptions, museums, concert halls and galleries in Africa do not have the budgets with which to call art into being. Curatorial institutions have to work opportunistically to build up collections, define genres and create a canon. For brokers of culture, there is a premium on creating beautiful things cheaply. 
The Uganda Museum in Kampala, for example, operates on an annual budget of around US $\$ 80,000$. The Ministry of Tourism, not the museum's curators, controls the funds. There is no budget for acquisitions. Over the course of decades, curators have built the collection by recycling and recontextualizing objects that were discarded by their creators. Many of the spears, swords and shields that are on display in the ethnographic gallery were, in a former time, court exhibitions. They had been seized by the police as evidence during investigations into murders and assaults. Once the case had been closed, the exhibits were kept in the court storeroom and, eventually, passed on to the museum. In a similar way, the museum's curators salvaged a number of drums, thrones and other regalia that had formerly belonged to Uganda's several kingdoms. The five kingdoms of Uganda had been abolished by law in 1967, as President Milton Obote consolidated power in his own hands. The accoutrements of royal prestige were rendered defunct and given over to museum curators to superintend. That is how the Uganda Museum became the final resting place for objects that had outlived their former lives. There they live a new life: not as police exhibits, not as either evidence of royal prestige or potential challenges to colonial authority, but as ethnographic specimens (Peterson 2015; Peterson and Abiti 2021).

Archives - like the collections of the Uganda Museum - have been constituted through the selective process of reclamation and repurposing. The first two articles in this collection discuss the work by which some papers are reclaimed from other destinies and made into archives. All archival work, the authors emphasize, is provisional. It relies on the ingenuity, knowledge and creativity of archivists to create and sustain the historical record. As Edgar Taylor points out, culling is an intrinsic part of any archival practice, for all archivists must balance the desire to preserve with the facts of overcrowded storerooms, limited budgets and overstretched staff. In the Ugandan context in which Taylor works, government papers have been kept in a state of disarray, stuffed into attics, basements or sheds, ordinarily with no catalogue. Taylor argues that this invisibility has been a necessary condition for the survival of government archives in tumultuous times. Archivists carefully evaluate the students and scholars who wish to consult government records, making judgements about their intentions, their politics, their reliability. In this way they mitigate risk, ensuring that controversial or objectionable paperwork does not make its way into the public domain. Here is a form of curatorship that is discriminatory. Archivists' work is not to encourage transparency, openness or access; instead, it is to ensure that incendiary or objectionable paperwork does not get into the public domain.

Taking things out of circulation - rendering them hard to find - is part of the work that archivists in politically constrained circumstances must do. The second article, by Benedito Machava and Euclides Gonçalves, focuses on the 'arquivo morto', the 'dead archive' in which the papers of Mozambique's government are interred. Like the Portuguese colonial officials before them, socialist officials documented everything, and the archival record of socialist Mozambique is correspondingly rich and detailed. More recently, the post-socialist government has turned away from its activist efforts to mobilize and monitor Mozambican citizens. As Machava and Gonçalves describe it, government archives are an "unpalatable" collection of cold reports about development projects, lists of functionaries, and dry summaries of administrative expenditure'. Much is kept secret. Guarding, concealing and hindering access to information 
is the hallmark of the post-socialist state. 'Dead archives' have proliferated, as government information has been occluded from public view.

The call for transparency and open government is grounded in the liberal premise that a watchful citizenry, once provisioned with information, will hold leaders to account. But archival preservation is always selective; there are always limits of space and materials. In that sense austerity is woven into the method of archive preservation: it necessarily involves the management of shortage. In places where governments have secrets to hide, the spaces for free access are smaller. Destruction, blockage and the holding back of information are generative of forms of authority. In the Ugandan archives that Taylor describes, as in the collections that Machava and Gonçalves survey, the physical blockages to access - swarms of wasps, piles of disused office furniture, the accumulation of uncatalogued and disorganized paperwork - function effectively as a vehicle for the keeping of secrets. They are barricades that both protect information and block inconvenient investigations. At the same time, they act as a means of elevating the authority of archivists, whose professional knowledge of the material allows them to exercise power over the flow of paperwork.

\section{The work of art}

Nearly all forms of culture obscure the conditions that gave birth to them. Books, once published, assume a standardized form. They become portable and can be placed on shelves and read without regard to the identity of the author, publisher or printer. Musicians knowingly subordinate their personalities, interests and desires to fit within a coordinated, integrated performance. That is what rehearsal entails: the subordination of idiosyncrasy, the pursuit of expertise, regimentation, synchrony. The same is true of theatre: actors must dispossess themselves of their own identities and work according to the script. And museum visitors, too, have no inkling of the labour involved in the erection of public exhibitions. In these and in other media, performers, artists and curators render their work invisible. Culture in this sense is the abstraction of human labour (Magaziner 2016).

This collection of articles makes visible the uncompensated human labour that upholds the production of culture in Africa. A whole field of work is conducted out of sight, behind closed doors, in private spaces where artists prepare to appear before their public. An equally consequential field of human exertion entails the construction and maintenance of public buildings, monuments, theatres and other venues for cultural activity. Even the most impressive, the most solid, the most apparently permanent cultural forms require human initiative, knowledge and expertise. Permanence and solidity are themselves illusory. Natural forces the growing of trees, the erosion of soil, the drying of mortar - always impinge upon the monument, the building, the triumphal arch, making it crack, list, and eventually disappear. Maintenance is always necessary.

The advancing pace of decrepitude imposes a sacrifice upon the people who act as curators of monumental works. This is particularly true in places where cultural sites are constructed of organic materials, where concrete - which slows the onward pace of decrepitude - is in short supply. In western Uganda, for instance, there are dozens of tombs where the rulers of the ancient kingdom of Bunyoro are 
buried. All of them have survived as monumental sites due to the constant labour and attention of commoners. In the 1970s, the government of Idi Amin celebrated the famous warrior king of Bunyoro, Kabalega, as an inspirational source of historical orientation. But Kabalega's tomb was in a state of dereliction, and the regalia kept on the site was being eaten by termites. There had been plans in place to build the tomb of the king in concrete, at a cost of 60,000 shillings. In the end, government allocated a bare 1,000 shillings to the project. ${ }^{3}$ It fell to local people to undertake the necessary work of keeping the site open. When the reed fence around the site collapsed in heavy winds, an official from Kampala ordered the sub-county chief to marshal a working squad within two days to clear the site and to smooth the road leading to the tomb. ${ }^{4}$ Neither the materials nor the labour were compensated.

That is how - through routine acts of repair and maintenance - culture has been preserved. In Uganda, as in other places, ordinary people - their labour, their time, their treasure - were called upon to maintain myths (Peterson, this issue). Some people acted out of a sense of devotion, out of imaginations that were fired by the requirements of the time. Other people were compelled to take part. Whether out of a sense of patriotic enthusiasm or personal responsibility, commoners have undertaken the task of preserving history.

In the second part of this collection of articles, the historian Maria Suriano introduces us to a publisher - Walter Bgoya - who, over the course of decades, has sacrificed himself to uphold Tanzania's intellectual cultural production. Bgoya's career as a publisher began in the early 1970s, when he took up a post in the Tanzania Publishing House. As Suriano describes, the Tanzania Publishing House always had to operate under austere conditions: in the mid1970s a shortage of spare parts led to regular stoppages in printing, and shortages of paper made books expensive. By the 1980s, foreign companies had come to control most of Tanzania's publishing business. Bgoya, seeking to expand opportunities for local publishers, founded his Mkuki na Nyota publishing house in 1991. It was a massive piece of work: Bgoya commissioned the works, did the editing, checked the proofs, and managed sales and distribution. The demands on his time and energy were by no means suitably compensated. Bgoya feels a proprietary responsibility for his authors: he sees publishing as 'an engagement ... It's a relationship that develops: the closer the better.' It is this sense of responsibility that leads him to undertake the self-sacrificing work of running his publishing business.

Walter Bgoya was by no means the only Tanzanian entrepreneur who had to respond creatively to the challenges of postcolonial austerity. Emily Callaci's work on 'street publishers' in 1970s Dar es Salaam brings to light a whole field of literary activity that was defined by shortages of paper, funding and markets (Callaci 2017). In the absence of support from government, dozens of Tanzanian writers composed short novels - mostly in Swahili - that they photocopied, stapled, and sold on the streets of Dar es Salaam. These novels

\footnotetext{
${ }^{3}$ Hoima District Archive, PUW box 1026, file 3: Conservator of Antiquities to Minister of Culture and Community Development, 8 August 1974.

${ }^{4}$ Hoima District Archive, PUW box 1026, file 3: Sam Byagira to Muluka Chief Butima, 24 April 1975.
} 
took urban life itself as their subject: they were about the 'hustlers', 'street walkers' and 'con men' who inhabited the city. They were sold on street corners, often by the authors themselves. The men who wrote them came to be called 'briefcase publishers'. Here was a form of literary creativity that worked within the shortages of the times, generating new literary forms and new circuits of distribution.

There is a substantial distance in prestige and reputation between the 'briefcase publishers' of Dar es Salaam's streets and the professionally produced books that Walter Bgoya prints, but seeing them in the same frame brings to light the ways in which enthusiasm, ambition and a sense of obligation animate the work of publishing. Like the briefcase publishers, Bgoya feels a responsibility to his audience, the moral conviction of obligation. It is the proximity between publisher and audience, between producer and purpose, that animates his life of self-sacrifice.

Marlino Mubai's article shows that, in post-socialist Mozambique, as in Tanzania, diminishing state provisions for institutions of learning have obliged knowledge workers to expand their repertoires. Mubai exposes the forwardlooking, innovative and risky ways in which Mozambican university faculty have responded to shortfalls in government financing - from hiring themselves out as consultants to seeking additional teaching opportunities and sources of income. Ironically, the expansion of private higher educational facilities and institutes has given scholars greater autonomy to challenge the status quo, but this freedom comes at the cost of systemic uncertainty and precarity associated with drastically reduced public funding. These same changes have attended the transformations of universities in many other places in Africa (Mamdani 2007).

The final article in the collection, from Derek R. Peterson, explores the political effects of the de-professionalization of public life. When experts cannot exercise technocratic power, what new forms of political subjectivity become thinkable? In Idi Amin's Uganda - as in post-socialist Mozambique and contemporary Tanzania - representative institutions were starved of resources, and civil servants were obliged to improvise. Demands were made on Ugandan commoners, too. There was a rapid de-professionalization of public institutions, as commoners without credentials marshalled talent and resources to subsidize government work. Peterson argues that all of this encouraged black Ugandans to see themselves as proprietors of public life. The sacrifices they made endowed them with a feeling of ownership over infrastructures, economies and institutions. The 1972 expulsion of the Asian community - and other campaigns that targeted minority owners of Uganda's cultural economy - was a consequence of the impulse to distinguish the owners of civic institutions from interlopers, freeloaders and other unentitled people. The dispossession of outsiders came to be cast as the reclamation of a majority's destiny, the recovery of a birthright, a liberation.

The articles in the second part of this collection demonstrate that, under conditions of austerity, the relationship between the producers and consumers of knowledge is rearranged. There is little space for the exercise of expertise that would be recognized as such, or for the cultivation of a narrow field of knowledge. Without the material means to shore themselves up, academic disciplines, government institutions and other bulwarks of expert authority are dramatically opened up. Professors - habituated into the slow routines of academic knowledge production - are obliged to turbocharge their work, moving rapidly from one institution to another to survive. Publishers have to become skilful in a huge 
number of tasks. At the same time, people without credentials are empowered to see themselves as authorities, playing - by right - a proprietary role in public life.

In one sense, the rearrangements that accompany austerity engender a more democratic relationship between producers and consumers of knowledge. In another sense, the diminution of institutions' ability to maintain the currency of expertise opens the door to demagoguery. Deprived of their power to adjudicate, the institutions that curate knowledge are opened to the passions and prejudices of the majority.

\section{Conclusion}

As we write this introduction, the Covid-19 pandemic has unveiled the awful mechanics of austerity in the wealthy societies of the global North. Artists and performers have been endangered. According to one accounting, two-thirds of the artists in the United States are unemployed as a result of the disruptions caused by the virus. Some 12,000 arts and culture organizations are unlikely to survive the pandemic and the upsets that have attended it. ${ }^{5}$

It has fallen to artists, expert administrators and teachers to find resources, technology and time to create, superintend and educate (Midgette 2020). Orchestras and choirs are performing remotely, through Zoom and other digital interfaces. Museums are offering digital tours of their collections. To many, the proliferation of digital venues is a welcome advance, a door opening onto forms of artistry and knowledge work that are otherwise closeted. But the work that these stewards of culture perform is unevenly compensated, if compensated at all. All of it relies on the labour of people who must pay for their own internet access, who must practise and hone their craft and expertise on their own time and at their own expense, who do not have health insurance, whose creative improvisation must occur in time that is stolen from other endeavours. The pandemic has exacerbated a longerterm dynamic: the production of beauty and knowledge, the work of education, and the enrichment of public culture are increasingly dependent on the selfsacrifice of artists, creators and educators. Many others, though, are benefiting in the process.

What does starting the conversation about austerity capitalism from the vantage of sub-Saharan Africa lend to the emergent situation of the global North? Following Jean and John Comaroff, we take seriously the possibility that it has been 'regions in the South that tend first to feel the concrete effects of world-historical processes as they play themselves out', sometimes prefiguring the former metropole and the global North more broadly (Comaroff and Comaroff 2012: 121). By exposing the material conditions and historical contexts in which art, culture and knowledge are generated, the labour, enthusiasm, opportunism and commitment of public intellectuals and unsung stewards of culture and institutions come into focus. Through their work, it is possible to see how austerity itself generates new forms of culture, new challenges, and new

\footnotetext{
5'Covid-19's impact on the arts: research update May 4', Americans for the Arts, 4 May 2020 $<$ https://www.americansforthearts.org/news-room/americans-for-the-arts-news/covid-19-impacton-the-arts-research-update-may-4-2020>, accessed 19 June 2020.
} 
constraints, encouraging the pursuit of novel forms of curatorship, pedagogy and politics. In the study of material life, the backstage of public culture and the possibilities for its future come into view.

\section{References}

Arrighi, G. (2007) Adam Smith in Beijing: lineages of the 21st century. London: Verso.

Barber, K. (2006) Africa's Hidden Histories: everyday literacy and making the self. Bloomington IN: Indiana University Press.

Bayart, J.-F. (2010) Les Études Postcoloniales: un carnaval académique. Paris: Karthala.

Bear, L. (2015) Navigating Austerity: currents of debt along a South Asian river. Palo Alto CA: Stanford University Press.

Bear, L. (2017) 'Anthropological futures: for a critical political economy of capitalist time: ASA's Raymond Firth Lecture, 2016', Social Anthropology 25 (2): 142-58.

Berry, S. (1992) 'Hegemony on a shoestring: indirect rule and access to agricultural land', Africa 62 (3): 327-55.

Bierschenk, T. (2014) 'Sedimentation, fragmentation and normative double-binds in (West) African public services' in T. Bierschenk and J.-P. Olivier de Sardan (eds), States at Work: dynamics of African bureaucracies. Leiden: Brill.

Blyth, M. (2013) Austerity: the history of a dangerous idea. Oxford: Oxford University Press.

Branch, D. (2009) Defeating Mau Mau, Creating Kenya: counterinsurgency, civil war, and decolonization. Cambridge: Cambridge University Press.

Breckenridge, K. (2014) Biometric State: the global politics of identification and surveillance in South Africa, 1850 to the present. Cambridge: Cambridge University Press.

Callaci, E. (2017) Street Archives and City Life: popular intellectuals in postcolonial Tanzania. Durham NC: Duke University Press.

Chalfin, B. (2010) Neoliberal Frontiers: an ethnography of sovereignty in West Africa. Chicago IL: University of Chicago Press.

Comaroff, J. and J. L. Comaroff (2012) 'Theory from the South: or, how Europe is evolving toward Africa', Anthropological Forum 22 (2): 113-31.

Cooper, F. (2001) 'What is the concept of globalization good for? An African historian's perspective', African Affairs 100 (399): 189-213.

Cooper, F. (2002) Africa since 1940: the past of the present. Cambridge: Cambridge University Press.

Dubow, S. (1989) Racial segregation and the origins of apartheid in South Africa, 1919-36. New York: Palgrave Macmillan.

Eckert, A. (2014) "“We must run while others walk": African civil servants, state ideologies and bureaucratic practices in Tanzania, from the 1950s to the 1970s' in T. Bierschenk and J.-P. Olivier de Sardan (eds), States at Work: dynamics of African bureaucracies. Leiden: Brill.

Freund, B. (2010) 'The social context of African economic growth 1960-2008' in V. Padayachee (ed.), The Political Economy of Africa. New York NY: Routledge. 
Guy, J. (2013) Theophilus Shepstone and the Forging of Natal: African autonomy and settler colonialism in the making of traditional authority. Scottsville: University of KwaZulu-Natal Press.

Hamani, O. (2014) “We make do and keep going!" Inventive practices and ordered informality in the functioning of the district courts in Niamey and Zinder (Niger)' in T. Bierschenk and J.-P. Olivier de Sardan, States at Work: dynamics of African bureaucracies. Leiden: Brill.

Harper, J. (2006) Western-educated Elites in Kenya, 1900-1963: the African American factor. London: Routledge.

Harrison, G. (2007) 'Debt, development and intervention in Africa: the contours of a sovereign frontier', Journal of Intervention and Statebuilding 1 (2): 189-209.

Ivaska, A. (2011) Cultured States: youth, gender, and modern style in 1960s Dar es Salaam. Durham NC: Duke University Press.

Lal, P. (2015) African Socialism in Postcolonial Tanzania: between the village and the world. Cambridge: Cambridge University Press.

Lentz, C. (2014) "I take an oath to the state, not the government": career trajectories and professional ethics of Ghanaian public servants' in T. Bierschenk and J.-P. Olivier de Sardan, States at Work: dynamics of African bureaucracies. Leiden: Brill.

Liesegang, G. (2000) 'The Arquivo Histórico de Moçambique and historical research in Maputo', History in Africa 27: 471-7.

Machava, B. (2018) 'The morality of revolution: urban cleanup campaigns, reeducation camps, and citizenship in socialist Mozambique, 1974-88'. $\mathrm{PhD}$ thesis, University of Michigan.

Magaziner, D. (2016) The Art of Life in South Africa. Athens OH: Ohio University Press.

Mamdani, M. (1996) Citizen and Subject: contemporary Africa and the legacy of late colonialism. Princeton NJ: Princeton University Press.

Mamdani, M. (2007) Scholars in the Marketplace: the dilemmas of neo-liberal reform at Makerere University, 1989-2005. Dakar: CODESRIA.

Mann, G. (2014) From Empires to NGOs in the West African Sahel: the road to nongovernmentality. Cambridge: Cambridge University Press.

Martin, T. M. (2015) 'Managing with escapes: human rights and practical norms in West African bureaucracies' in T. De Herdt and J.-P. Olivier de Sardan (eds), Real Governance and Practical Norms in Sub-Saharan Africa: the game of the rules. London: Routledge.

Matthew, F. D. (1880) The English Works of Wyclif. London: Early English Text Society.

Midgette, A. (2020) 'Furloughed musicians and a new digital frontier: performing arts in the COVID-19 shutdown', Vanity Fair, 27 April.

Monga, C. (2016) Nihilism and Negritude: ways of living in Africa. Cambridge MA: Harvard University Press.

Newitt, M. (1995) A History of Mozambique. Bloomington IN: Indiana University Press.

Ngunga, A. (1999) 'Literacy campaigns in Mozambique: why did they fail?', Language Matters: Studies in the Languages of Africa 30 (1): 147-56.

Olivier de Sardan, J.-P. (2015) 'Practical norms: informal regulations within public bureaucracies' in T. De Herdt and J.-P. Olivier de Sardan (eds), Real Governance 
and Practical Norms in Sub-Saharan Africa: the game of the rules. London: Routledge.

Park, E. (2017) 'Infrastructural attachments: technologies, mobility, and the tensions of home in colonial and postcolonial Kenya'. PhD thesis, University of Michigan.

Peterson, D. (2015) 'Introduction: heritage management in colonial and contemporary Africa' in D. Peterson, K. Gavua and C. Rassool (eds), The Politics of Heritage in Africa: economies, histories, and infrastructures. Cambridge: Cambridge University Press.

Peterson, D. and N. Abiti (2021) 'Collecting obsolete things at the Uganda Museum' in R. Silverman, P. Probst and G. Abungu (eds), National Museums in Africa: reflections on memory, identity, and the politics of heritage. London: Routledge.

Piot, C. (2010) Nostalgia for the Future: West Africa after the Cold War. Chicago IL: University of Chicago Press.

Pitcher, M. A. (1993) Politics in the Portuguese Empire. Oxford: Oxford University Press.

Pitcher, M. A. (2002) Transforming Mozambique: the politics of privatization, 1975-2000. Cambridge: Cambridge University Press.

Rodney, W. (1972) How Europe Underdeveloped Africa. Washington DC: Howard University Press.

Roitman, J. (2013) Anti-Crisis. Durham NC: Duke University Press.

Ross, W. McGregor (1968) Kenya from Within: a short political history. London: Allen \& Unwin.

Rottenburg, R. (2009) Far-fetched Facts: a parable of development aid. Cambridge MA: MIT Press.

Vail, L. and L. White (1980) Capitalism and Colonialism in Mozambique: a study of Quelimane District. Portsmouth NH: Heinemann.

van Waijenburg, M. (2018) 'Financing the African colonial state: the revenue imperative and forced labor', Journal of Economic History 78 (1): 40-80. 